\title{
POLITICAL ECONOMY, IDEOLOGY AND THE PERSISTENCE OF WORKING-CLASS HOUSING PROBLEMS IN BRITAIN, 1850-1914*
}

Nineteenth-century housing was not all gloom and doom. For significant elements of the nation the standard of comfort and material welfare improved substantially. ${ }^{1}$ Suburbanization of the middle classes in the second half of the century appreciably improved environmental conditions, the family in particular benefitting from a semi-rural existence with only the commuting breadwinner subject to the hostility of urban conditions. ${ }^{2}$ In the last third of the nineteenth century rising real incomes were especially beneficial to artisans and the more regularly employed labouring class. ${ }^{3}$ Linoleum, curtains, parlour furniture, even pianos transformed the immediate appearance of the home; shoes, a change of clothes and running water that of the people; and the kitchen range, water closets and gas mantles re-arranged the domestic patterns in other respects. ${ }^{4}$ The possibility of an

* Earlier versions of this paper were given as a public lecture at the University of Kansas, April 1983, and to a conference on housing history in Münster organized by the Historisches Seminar of the Westfälische Wilhelms-Universität. I am indebted to Prof. Dr. H. J. Teuteberg for permission to reproduce in translation sections of that paper, which appeared as "Die Krise des britischen Wohnungswesens 1830-1920" in H. J. Teuteberg [Ed.], Homo Habitans (Münster 1985). To the participants on those occasions I am grateful, as I am for the helpful observations of a referee for this paper.

1 D. Rubinstein, Victorian Homes (Newton Abbot, 1974), pp. 109-16.

2 G. Stedman Jones, Outcast London. A Study of the Relationship between Classes in Victorian Society (Oxford, 1971); H. J. Dyos, Victorian Suburb. A Study of the Growth of Camberwell (Leicester, 1964).

3 C. H. Feinstein, Statistical Tables of National Income, Expenditure and Output of the U.K., 1855-1965 (Cambridge, 1972), T 140; S. Pollard, "Trade Unions and the Labour Market, 1870-1914", in: Yorkshire Bulletin of Social and Economic Research, XVII (1965), pp. 98-112.

4 J. Burnett, A Social History of Housing 1815-1970 (Newton Abbot, 1978), pp. 168-73;

C. Davidson, A Woman's Work Is Never Done. A History of Housework in the British Isles, 1650-1950 (London, 1982). 
outing to the seaside was for many a realistic one, ${ }^{5}$ while the growth of organized sport created leisure possibilities, as did the expansion of clubs and other social activities. ${ }^{6}$

So fundamental and widespread were these improvements, it has been suggested, that the internal physical space of the working-class home was re-arranged. ${ }^{7}$ The separation of kitchen and living room effectively added another room, for example, taking smells of cooking out of the main socializing area in the home, and physically segregating women to a separate rather than an integrated existence in the home. While the catalogues of kitchen ranges, the production of baths, furniture and other domestic equipment reflect growing consumerism, this was by no means universal. ${ }^{8}$ Indeed for the unskilled, irregularly employed or sweated piece-rate worker, the segregation within the grades of manual workers and the increasing gap between rising expectations and actual living conditions may well have been more acutely felt. Trade-union organization and the extension of the franchise, for example, drove divisions between different components of the working class, ${ }^{9}$ and housing conditions served to reinforce this.

Recent research has stressed improvements in working-class dwellings through four channels: first, rising real incomes and consumption levels in the last third of the nineteenth century; ${ }^{10}$ second, philanthropic housing

5 J. K. Walton, The Blackpool Landlady. A Social History (Manchester, 1978) id., "The Demand for Working Class Seaside Holidays in Victorian England", in: Economic History Review, Second Series, XXXIV (1981), pp. 249-65; P. Bailey, Leisure and Class in Victorian England. Rational Recreation and the Contest for Control, 1830-1885 (London, 1978).

6 W. Vamplew, "The Influence of Economic Change on Popular Sport in England, 16001900', in: Proceedings of the First Australian Symposium on the History and Philosophy of Physical Education and Sport, ed. by R. Crawford (Melbourne, 1980), pp. 120-51; R. Price, "The Working Men's Club Movement and Victorian Social Reform Ideology", in: Victorian Studies, XV (1971-72), pp. 117-47.

7 M. Daunton, "Public Place and Private Space. The Victorian City and the Working Class Household", in: The Pursuit of Urban History, ed. by D. Fraser and A.R. Sutcliffe (London, 1983), pp. 212-33.

${ }^{8}$ See, for example, advertisements in The Builder, The Leisure Hour, The Englishwoman's Domestic Magazine, Illustrated London Magazine, The Ladies' Treasury, The Sixpenny Magazine, The Englishwoman's Review, and Cassell's Magazine.

9 For an overview of this subject, see E. J. Hobsbawm, "The Aristocracy of Labour Reconsidered", in: Worlds of Labour (London, 1984), pp. 227-51; als R. Q. Gray, "Styles of Life, the 'Labour Aristocracy' and Class Relations in Later Nineteenth Century Edinburgh", in: International Review of Social History, XVIII (1973), pp. 428 52.

${ }^{10}$ See for example J. Roach, Social Reform in England 1780-1880 (London, 1978); D. Ward, "The Victorian Slum: An Enduring Myth?", in: Annals of the Association of American Geographers, LXVI (1975), pp. 323-36; J. P. Lewis, Building Cycles and Britain's Growth (London, 1965); C. G. Pooley, "Residential Mobility in the Victorian City", in: Transactions of the Institute of British Geographers, IV (1979), pp. 258-77. 
initiatives; $; 1$ third, municipal intervention including housebuilding $;{ }^{12}$ fourth, town, garden-city and other utopian planning efforts. ${ }^{13}$ Most numerous have been the philanthropic, civic and planning studies, implicitly conveying the impression of improving living standards for the working class. This paper re-asserts a pessimistic view of the extent of such improvements, and argues that unless and until the Victorian ideology of nonintervention was put permanently aside, then the problem of housing the working class would be an enduring one. It also argues that such improvements as had taken place were both marginal in respect of the problem and limited to the income group of the artisans and above.

In a society geared towards systematized production in an increasing range of fields - whatever the reservations about Britain's comparative technological performance in the late-Victorian period ${ }^{14}$ - the subordination of craft skill to repetitive machine production was a powerful force for maintaining and enlarging the pool of unskilled labour as hostage to the vagaries of the trade cycle. For employers trade-cycle fluctuations were largely offset by forcing adjustments upon labour through lay-offs; for labour such frequent and sometimes extended bouts of unemployment meant a reduction in the average affordable rental, and the meanness of living conditions for much of the working class reflected this. During the

11 J. N. Tarn, Five Per Cent Philanthropy. An Account of Housing in Urban Areas between 1840 and 1914 (Cambridge, 1973); D. Owen, English Philanthropy, 1660-1960 (Cambridge, Mass., 1964); D. Hardy, Alternative Communities in Nineteenth Century England (London, 1979); J. N. Tarn, "The Improved Industrial Dwellings Company", in: Transactions of the London and Middlesex Archaeological Society, XXII (1968); id.,

"The Peabody Donation Fund", in: Victorian Studies, X (1966-67), pp. 7-38.

12 C. M. Allan, "The Genesis of British Urban Redevelopment with Special Reference to Glasgow", in: Economic History Review, Second Series, XVIII (1965), pp. 598-613; R. V. Steffel, "The Boundary Street Estate. An Example of Urban Redevelopment by the London County Council, 1889-1914", in: Town Planning Review, XLVII (1976), pp. 161-73; S. M. Gaskell, "Sheffield City Council and the Development of Suburban Areas prior to World War I", in: Essays in the Economic and Social History of South Yorkshire, ed. by S. Pollard and C. Holmes (Barnsley, 1976), pp. 187-202; P. J. Smith, "Planning as Environmental Improvement. Slum Clearance in Victorian Edinburgh", in: The Rise of Modern Urban Planning, 1800-1914, ed. by A. Sutcliffe (London, 1980), pp. 99-134.

${ }_{13} \mathrm{~J}$. N. Tarn, "Housing Reform and the Emergence of Town Planning in Britain before 1914", in: The Rise of Modern Urban Planning, pp. 71-98; G. Cherry, The Evolution of British Town Planning (New York, 1974); British Town Planning. The Formative Years, ed. by A. Sutcliffe (Leicester, 1981). See also A. Sutcliffe, The History of Urban and Regional Planning. An Annotated Bibliography (London, 1981), for further details on this subject.

14 D. H. Aldcroft and H. W. Richardson, The British Economy 1870-1939 (London, 1969); Essays on a Mature Economy. Britain after 1840, ed. by D. N. McCloskey (Princeton, 1971). 
nineteenth century the highest proportion of income spent on accommodation came from the poorest-paid, a position which was intensified as rentals tended to account for a rising percentage of income as the nineteenth century progressed. ${ }^{15}$ For the unskilled in particular, but for a broader working-class group too, exposed to the unrestricted workings of the labour and housing markets, unprotected by social legislation inhibiting the operation of either, in the absence of powerful trade unions to boost basic income levels and with re-distributive taxation inconceivable, nineteenth-century living conditions remained mean.

On the eve of World War I significant proportions of British society had only limited access to running water and sanitation; many were subject to severe overcrowding ${ }^{16}$ Individually such problems represented personal housing crises, if only because of the related difficulties which they spawned - public-health hazards, disease, lower life expectancy, high infant mortality, physical deformities, child-battering, moral degeneration, and alcoholism. ${ }^{17}$

If the level of analysis is aggregative rather than individual, the "housing problem" is shown in clearer relief, its magnitude exposed. In 22 out of 29 London registration districts the persons-to-houses ratio increased between 1851 and 1881 to an all-time high of 7.85 in $1881 .{ }^{18}$ In Scotland the same ratio increased by $47 \%$ in the period $1801-71 .^{19}$ By 1911 , over 758,000

15 Royal Commission on the Housing of the Working Classes (hereafter Royal Commission), First Report [Parliamentary Papers, 1884-85, XXX, C. 4402], p. 21, recorded that over $85 \%$ of the working class paid one fifth of their income in rent; almost $50 \%$ paid between a quarter and a half of their income in rent. The paradox of rising rentals yet decreasing building for rental can be reconciled by attention to the escalation of other costs to meet building regulations, lower labour productivity in building, increased taxation, etc.

${ }^{16}$ R. G. Rodger, "The Victorian Building Industry and the Housing of the Scottish Working Class", in: Building the Industrial City, ed. by M. Doughty (Leicester, 1986), pp. 151-206; see also Burnett, A Social History of Housing, op. cit., and M. J. Daunton, House and Home in the Victorian City. Working-Class Housing 1850-1914 (London, 1983), pp. 237-85.

17 According to Sir J. P. Dickson-Poynder, The Housing Question (London, 1909), p. 1, "The housing problem indeed may be said to be the sum total of all the social and economic problems which await solution."

18 London County Council, London Statistics, XII (1901-02), p. 10. See also Journal of the Statistical Society of London, XLVIII (1885), pp. 338-96, quoted in A. S. Wohl, The Eternal Slum. Housing and Social Policy in Victorian London (London, 1977), p. 23. 19 E. Gauldie, Cruel Habitations. A History of Working-Class Housing 1780-1918 (London, 1974), p. 145. 
Londoners, "more than the entire population of Liverpool, Manchester, or Birmingham, were living in overcrowded conditions." ${ }^{20}$ In those cities too, on the overcrowding standard of "more than two per room" some $10-12 \%$ of the urban population was overcrowded, and in the boroughs of Northumberland and Durham the proportion was in excess of $30 \% .{ }^{21}$ All this paled into insignificance when the 1911 census showed $55.7 \%$ of Glaswegians ( 420,000 souls) living more than 2 to a room. ${ }^{22}$ More than 1.4 million $(47.6 \%)$ Scots in burghs of 2,000 or more lived at a similar housing density, and nearly $10 \%$ of the population north of the border lived in one-roomed houses..$^{23}$

Table 1. Lunacy in various London parishes according to housing density, 1902

\section{Persons/acre Lunacy rate (\%o)}

$\begin{array}{lrr}\text { All London } & 58 & 1.9 \\ \text { Bethnal Green } & 171 & 6.7 \\ \text { Holborn } & 186 & 8.2 \\ \text { Strand } & 143 & 11.0\end{array}$

Source: W. Thompson, Housing Up-to-date (London, 1907), p. 5.

The impact of poor housing on physical and mental degeneration can be partly observed in Table 1, although, it is important to stress, not wholly determined by adverse housing circumstances. A similar relationship was shown to exist between housing density and alcoholism in a London County Council report, and elsewhere a systematic link between housing density and child battering has been demonstrated. ${ }^{24}$ Overcrowded housing conditions figured most prominently, however, in analyses of disease. In a lecture in St James' Hall, London, in 1901 the eminent bacteriologist Robert Koch argued, as reported in The Times, that

the only main source of the infection of tuberculosis was the sputum of consumptive patients [. . . ]. How was [. . . ] a helpless patient to remove his sputum so that it might do no harm? [ . . ] picture the condition of a poor consumptive patient's dwelling at night. The whole family slept crowded

20 Wohl, The Eternal Slum, op. cit., p. 301.

21 Census of England and Wales, 1911, Preliminary Report [Cd 5705].

22 Scottish Land Enquiry Committee, Report (London, 1914), p. 286.

23 Ibid., pp. 350-51.

${ }^{24}$ A. M. Williamson, The Influence of Housing on Health (privately published, 1917). 
together in one small room. However cautious he might be, the sufferer scattered the morbid matter secreted by his diseased lungs every time he coughed, and his relatives close beside him must inhale this poison. [ . . ] it was not poverty per se that favoured tuberculosis, but the bad domestic conditions under which the poor everywhere, but especially in great cities, had to live. [. . .] So it was the overcrowded dwellings of the poor that we had to regard as the real breeding places of tuberculosis $[\ldots]{ }^{25}$

Urban congestion, the proximity of neighbours or, as one author called it, "the contagion of numbers", ${ }^{26}$ was understandably correlated with high death rates, as can be seen from Table 2 - the more densely packed the urban population in back-to-back terraced houses, the higher the death rates in such areas. Furthermore the relationship between death rates and ventilation can be seen both in so far as back-to-back houses restricted ventilation in comparison to through houses, and according to street width, where mortality rates were inversely correlated with the distance between houses. ${ }^{27}$

The effects of such hostile living conditions were insidious at the personal level, socially serious at the aggregate level. Overcrowded housing, often 7 or 8 persons per house in Central London, ${ }^{28}$ disinclined adolescents to remain in the house in the evenings, and their street activities moved quickly in the passing of a few years from innocent street games to hooliganism, organized street crime and prostitution. ${ }^{29}$ Undisciplined at home, attendance at school was frequently sporadic and the ability to hold down regular employment questionable. Further limitations to employment prospects stemmed from reduced physical vitality, a deterioration which set in during childhood, where in height and weight children from overcrowded houses were conspicuously smaller than their contemporaries from larger houses, as Table 3 shows.

Glasgow boys from one-roomed houses were thus on average $10 \%$ smaller and $22 \%$ lighter than boys from four-roomed houses; girls were $11 \%$ smaller and $27 \%$ lighter than their counterparts from four-roomed houses. ${ }^{30}$ The rustic architecture of Lever's Port Sunlight model village on

25 The Times, 24 July 1901 , p. 8.

${ }^{26}$ J. A. Banks, "The Contagion of Numbers", in: The Victorian City. Images and Realities, ed. by H.J. Dyos and M. Wolff (2 vols; London, 1973), I, pp. 105-22.

${ }^{27}$ The same point could be made in relation to the ventilation of court and cellar dwellings and mortality rates.

${ }^{28}$ London Statistics, XII, table II, p. 116.

${ }^{29} \mathrm{E}$. Trudgill, "Madonnas and Magdalens. The Origins and Development of Victorian Sexual Attitudes in Literature and Society" (unpublished Leicester Ph.D. thesis, 1972). I am also grateful to R. S. Sindall for his helpful comments on these points.

${ }^{30}$ Calculated from Table 3. 
the opposite side of the Mersey to Liverpool recorded child giants by Merseyside standards; the children of these soap and chemical workers were larger and heavier than even the children of the well-to-do Liverpool citizenry in the Higher Grade Schools. ${ }^{31}$

\section{Table 2. Death rates and housing densities}

Housing type

Inhabitants

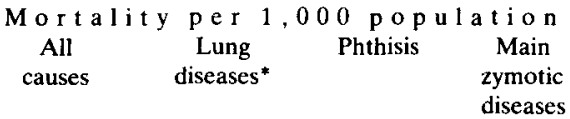

9.7

2.7

3.0

4.0

6.0

Shipley* (1887-92)

All houses

16,000

16.2

4.0

2.3

1.7

All back-to-backs

in 75-feet streets

in 45-feet streets

4,155

21.1

18.1

2,200

22.5

in 30-feet streets

1,245

710

\section{1}

1.7

4.9

3.4

2.8

5.7

4.1

1.8

28.1

4.6

2.9

*Excludes phthisis.

* ${ }^{*}$ Does not cover entire city.

Source: J. F. J. Sykes, Public Health and Housing. The Influence of the Dwelling upon Health in Relation to the Changing Style of Habitation (London, 1901).

Table 3. Physical differences of children according to house size, 1907

Glasgow $(36,883$ boys $)$

Average of all boys aged $5-18$

Liverpool

Schoolboys from smallest houses intermediate houses largest houses model housing in 1-room houses in 2-room houses in 3-room houses in 4-room houses 7 -year olds Height in inches

44.0
44.3
47.0
47.0

\section{Weight} in pounds
Height
in inches

43.0

43.0

49.3

50.5

55.2

56.2

61.7

62.2
Weight in pounds

$\begin{array}{cc}46.6 & 52.6 \\ 48.1 & 56.1 \\ 50.0 & 60.6 \\ 51.3 & 64.3 \\ \begin{array}{c}14-\text { y e a r } \\ \text { Height }\end{array} & \begin{array}{c}\text { o d s s } \\ \text { Weight } \\ \text { in inches }\end{array} \\ \text { in pounds }\end{array}$

71.1

75.8

94.5 108.0

Source: Report of the Physical Condition of Children Attending the Public Schools of the School Board for Glasgow [Cd 3637] (1907), p. v.; W. Thompson, Housing up-to-date (London, 1907), pp. 3-5.

31 Lord Leverhulme, Six Hour Day and Other Industrial Questions (London, 1918). 
Aged 7, 11 or 14 , boys in Port Sunlight were from $6-11 \%$ taller than their Liverpool contemporaries; their weight was from $15 \%$ greater aged 7 to an average $44 \%$ greater aged $14 .{ }^{32}$ In the light of such data, particularly for inner-city areas in relation to suburban and working-class communities sited away from the urban environment, it is perhaps more comprehensible why so many Boer War recruits were rejected, and why British social policy at the beginning of the twentieth century shifted emphatically in favour of the protection of children through school meals, milk and medical inspection as well as through midwifery and day care. ${ }^{33}$

Whatever the attempts to deal with the "Housing Problem", "Rookeries" or other evocative descriptions of Victorian housing, the magnitude of the problem remained seemingly intractable. ${ }^{34}$ As the data in Tables 1-3 show, whatever the limitations which might have been imposed during the Victorian era, the Edwardians inherited severe environmental problems in the cities. And these problems were recognized and variously perceived by numerous groups. To the ratepayer hospitals for infectious diseases, lunatic asylums, workhouses and poor relief represented substantial capital outlays and recurrent charges raised from local taxation. ${ }^{35}$ For example, the total capital expenditure on institutional building has been estimated at $£ 32$ million by $1905,{ }^{36}$ and although the total disappearance of such financial obligations would be impossible, attention to the impact of defective housing on the inmates population was seriously urged on the grounds of ratepayers' economy. Furthermore the loss of employment due to sickness and premature death on account of preventable disease disposed those who observed the faltering performance of the British economy after 1870 to argue for improved environmental conditions in general and housing reform in particular. The introduction of social insurance in Bismarkian Germany and satellites such as Uruguay, Denmark and New Zealand only

32 Ibid.

${ }^{33}$ M. Bruce, The Coming of the Welfare State (London, 1961), p. 192.

${ }^{34}$ Wohl, The Eternal Slum, pp. 353-54, provides almost 70 contemporary references in which such emotive descriptions are incorporated in the titles. H. J. Dyos, "The Slums of Victorian London", in: Victorian Studies, XI (1967-68), pp. 5-40, has an appraisal of many of these evocative titles.

${ }^{35}$ N. McCord, "Ratepayers and Social Policy", in: The Origins of British Social Policy, ed. by P. Thane (London, 1978), pp. 21-35.

${ }^{36}$ W. Thompson, Housing Up-to-date (London, 1907), p. 5. 
added succour to that cause in view of the self-doubts regarding Britain's imperial role and defensive capabilities in the light of the Boer War experience. ${ }^{37}$

From trade unions, too, the effects of inadequate housing drew expressions of alarm. Between 1892 and 1901, 100 principal trade unions spent more than $£ 2.5$ million on sickness benefit ${ }^{38}$ a drain, partly unavoidable of course, on their resources at a time when their legal status, the protection of their funds against actions for damages and the legality of picketing were central to their existence. Drains on their financial resources from whatever source were undesirable. Friendly societies, also, found themselves paying out substantial sums - $£ 3.25$ million in 1904 , for example - equivalent to $£ 1$ per member. ${ }^{39}$

The housing problem in Victorian Britain could not be more effectively represented than through the moral crisis revealed in A. Mearns's The Bitter Cry of Outcast London, published in $1883 .{ }^{40} \mathrm{~A}$ trio of congregational clergymen combined to describe hostile housing conditions in London. Non-attendance at worship was a major concern in the capital as it was in provincial cities, for without it Victorian reliance upon self-help and selfimprovement through personal revelation was unlikely. A spiritual resurrection which encouraged reformed personal lives was thought remote if slum-dwellers were not church-goers. ${ }^{41}$ Mearns's painstaking research conclusively demonstrated that the poor were not being exposed to church teaching. In London's Old Ford parish, for example, in 118 of 147 houses of the respectable working class nobody went to church. ${ }^{42}$ Of 246 families in a street adjoining Leicester Square only 12 ever crossed the threshhold of a church, and in St George's in the East parish 39 only out of the 4,235 attended church, and some of those on an occasional basis only. "Constantly", the pamphlet affirmed, "we come across persons who have never been to church or chapel for 20 years, 28 years, more than 30 years". ${ }^{43}$ Compassion, of course, as well as spiritual concern, permeated accounts of the living conditions: "Have you pitied the poor creatures who sleep under

37 J. R. Hay, The Origins of the Liberal Welfare Reforms, 1906-14 (London, 1975).

38 Thompson, Housing Up-to-date, op. cit.

39 Ibid.

40 Mearns, The Bitter Cry of Outcast London, ed. by A. S. Wohl (Leicester, 1970).

${ }^{41}$ For a synopsis of Victorian attitudes to poverty and self-help, see M. E. Rose, The

Relief of Poverty 1834-1914 (London, 1972), and the annotated bibliography.

${ }^{42}$ Mearns, The Bitter Cry, op. cit., p. 57.

43 Ibid. 
railway arches, in carts or casks, or under any shelter which they can find in the open air?" 44

Concern for morality was a recurrent issue in Mearns's pamphlet and indeed amongst a large number of Victorians. ${ }^{45}$ From the forced, illegal suicides to the household where "nine brothers and sisters, from 29 years of age downwards, live, eat and sleep together" 46 moral objections were raised. Elsewhere a mother "turns her children into the street in the early evening because she lets her room for immoral purposes until long after midnight, when her poor little wretches creep back again if they have not found some miserable shelter elsewhere." ${ }^{47}$ Moral concern often focussed on marriage - an unfashionable institution for many. Mearns quoted his experience: "Ask if the men and women living together in these rookeries are married, and your simplicity will cause a smile. Nobody knows. Nobody cares. Nobody expects they are." ${ }^{48}$ Such reports were largely duplicated in the Royal Commission on the Housing of the Working Classes, where frequent references to moral degeneracy were cited. ${ }^{49}$ Successive bouts of co-habitation caused as much moral concern as anything, both for its own sake and for its impact on dislocated family life. Prostitution was another problem. In one London parish of 10,000 where there were 400 prostitutes, Mearns's conclusion, if morally alarmed, was conspicuously tolerant.

That people condemned to exist under such conditions take to drink and fall into sin is surely a matter for little surprise. We may rather say [. . . ] that they are "entitled to credit for not being twenty times more depraved than they are." One of the saddest results of this over-crowding is the unavoidable association of honest people with criminals. [ . . ] Who can wonder that the public-house is "the Elysian field of the tired toiler?"so

Such atmospheric descriptions of living conditions in the 1880's touched the public conscience, sparked the public consciousness. It was further fired by Booth's and Rowntree's conclusion that at least $30 \%$ of Britons lived below the poverty line, a stark revelation in comparison to the Poor Law Commissioners' complacent assessment that recorded only $3 \%$ as paupers. ${ }^{51}$ More seriously, however, such vivid descriptions captured a

44 Ibid., p. 58.

${ }^{45}$ Most contemporary tracts pay some attention to this issue.

${ }^{46}$ Mearns, The Bitter Cry, p. 59.

${ }^{47}$ Ibid.

${ }^{48}$ Ibid., p. 61.

49 Royal Commission, First Report, p. 13; E. Trudgill, "Prostitution and Paterfamilias", in: The Victorian City, op. cit., II, pp. 693-705.

so Mearns, The Bitter Cry, pp. 60-61.

$\$_{1}$ Rose, The Relief of Poverty, op. cit., pp. 15, 53-54; Bruce, The Coming of the Welfare State, op. cit., pp. 143-46. 
crisis in Victorian self-confidence, visibly shaken by the evident inability after a century of industrialization to counteract the evils of slum dwelling.

It was not, of course, that housing conditions alone directly caused such social ills as prostitution, co-habitation, intemperance, irreligiousness, violence and physical deformities, but the spatial distribution of these closely corresponded with slum housing. Housing and conditions within the home, therefore, became increasingly identified with an assault on wider social problems. This gradual recognition, empirically derived, that the poor lived in such conditions not by choice or through idleness as claimed in mid-Victorian decades, but largely through force of circumstance, specifically the nature of their sporadic employment experience, re-directed attitudes to housing from laissez-faire to interventionism. Contemporary analyses of the labour market offered a sharper perspective on housing problems in the 1880 's, which prompted new vigour in the form of slum clearances, council housebuilding, cheap transit, garden suburbs and urban planning in the years before 1914, though achievements in these fields remained modest in relation to the scale of the problems with which they were confronted.

\section{III}

What was the prevailing approach to housing, therefore, which had generated such grave problems? Since the 1830's nascent liberalism stressed individualism and self-determination. Individuals were therefore responsible for their own welfare. The dictates of the urban labour market, principally the need for an enlarged, cheap and mobile supply of labour, and the regime of factory life together with the restraints upon labour inherent in low wages became the basis of a new social order in earlyVictorian Britain. The social relations of a formerly agricultural country were inconsistent with the requirements of a rapidly maturing industrial power, and in this climate of opinion residual relief responsibilities were fundamentally changed with the self-imposed test of destitution which became an integral part of the New Poor Law of $1834 .^{52}$

This prevailing philosophy of self-help and personal responsibility, together with the sanctity of property rights, bears much of the responsibility for the slum conditions so abhorrent to Mearns, Booth and other

52 For a discussion of the Old and New Poor Laws, see J. D. Marshall, The Old Poor Law, 1795-1834 (London, 1968); Rose, The Relief of Poverty. More generally on government thinking see W. C. Lubenow, The Politics of Government Growth. Early Victorian Attitudes toward State Intervention (Newton Abbot, 1971). 
social investigators of the 1880 's. Over the preceding fifty years or so this prevailing non-interventionist philosophy allowed residential building to proceed constrained by only the most minimal requirements regarding structural strength, sanitary and other internal arrangements, building alignment and general building standards..$^{53}$ At no other time was a tough building code and active municipal supervision more necessary than during the nineteenth century, when the total population doubled between 1801 and 1851, and doubled again between 1851 and 1901. ${ }^{54}$ The urban sector expanded at twice the national rate for much of the century. Even in Scottish burghs, where a stronger supervisory building agency, the Dean of Guild Court, had monitored building activity in many cases from the twelfth century, the 1830's witnessed their emasculation when the reform of local government nominally transferred such duties to the town council, duties which in the prevailing ideological climate were rarely if ever discharged..$^{55}$

Local-government reform on both sides of the border in the 1830's, generated in a national political climate of liberalism, carried over that philosophy to the civic level where builders, landlords, developers and other interested parties were, even in the face of mounting urban congestion, able to justify the absence of building controls. Indeed the town clerk of Leeds, in arguing against a bill to ban back-to-back housing paradoxically before Parliament at the same time as Chadwick's Report on the Sanitary Condition of the Labouring Population, was briefed by builders in Leeds who advised him that costs would rise $30 \%$ if back-to-back housing were banned, ${ }^{56}$ a position endorsed two years later in Thomas Cubitt's evidence to the Royal Commission on the State of Large Towns, in 1844, when he stated that "it [back-to-back housing] is a much cheaper mode, and if we prevent it we prevent houses for the accommodation of poor people." ${ }^{57}$ The local political climate was therefore overtly hostile to any

${ }_{53}$ S. M. Gaskell, Building Control. National Legislation and the Introduction of Local Bye-laws in Victorian England (London, 1983); R. H. Harper, "The Evolution of the English Building Regulations 1840-1914” (unpublished Ph.D. thesis, Sheffield, 1978).

${ }^{54}$ B. R. Mitchell and Ph. Deane, Abstract of British Historical Statistics (Cambridge, 1962), pp. 24-27; Interdepartmental Committee on Social and Economic Research, Guide to Official Sources No 2: Census Reports of Great Britain, 1801-1931 (1951).

${ }_{55}$ R. G. Rodger, "The Evolution of Scottish Urban Planning", in: Scottish Urban History, ed. by G. Gordon and B. Dicks (Aberdeen, 1983), pp. 71-91.

${ }_{56}$ M. W. Beresford, "The Back-to-Back House in Leeds, 1787-1937", in: The History of Working-Class Housing. A Symposium, ed. by S. D. Chapman (Newton Abbot, 1971), p. 112.

57 Royal Commission on the State of Large Towns and Populous Districts, First Report [PP, 1844, XVII], p. 176; Select Committee on the Health of Towns [PP, 1840, XI], p. 277. 
curtailment of builders' independence of action, a position builders vigourously sought to defend throughout the century, and municipalities were able only from the 1860 's to obtain modest and often unenforced building controls by adopting the "Form of Byelaws" in the Local Government Act, 1858. An effective, standardized pattern of building byelaws was available only from 1877 in England and Wales (1892 in Scotland), and in London, until the formation of the London County Council in 1889 , the fragmentation of political structures and the division of environmental responsibilities amongst vestries, street, lighting and other committees ensured an unco-ordinated approach to housing development despite the availability of a revised Metropolitan Building Act after 1844. ${ }^{58}$

The durability of Victorian housing was such that the life span of houses was frequently 60 or even 100 years. In any one year very small percentages could be added to, or removed from, the housing stock. Consequently the inheritance of those years of uncontrolled building in the early and mid nineteenth century, when urbanization was proceeding very rapidly, meant that this legacy could only slowly be counteracted. Building regulations, adopted in the 1860's and 1870's, might restrain the worst excesses of overcrowded and unsanitary conditions in new properties, but they could not eradicate the defects in the existing housing stock. Only when such defects threatened public safety - and that usually meant when diseases such as cholera and typhus threatened to invade the residential zones of the local political elites - were measures adopted to deal with the worst housing conditions. ${ }^{59}$ Even then these were often only instigated by the representations of private individuals, rather than by a reluctant municipality under the limited provisions of the Nuisance Removal Acts.

In this non-interventionist climate the internal structure of the building industry contributed substantially to mid-Victorian housing problems. The character of the product itself, it has already been observed, created a longterm legacy of housing problems. In addition, the minimal levels of capital required to set up as builder, absence of any proven competence, and the

58 D. Owen, The Government of Victorian London 1855-1889. The Metropolitan Board of Works, the Vestries and the City Corporation (Cambridge, Mass., 1982), pp. 47-48, 116-17; J. Roebuck, Urban Development in Nineteenth Century London. Lambeth, Battersea and Wandsworth 1838-1888 (London, 1979), pp. 46-50; Gaskell, Building Control, op. cit., p. 27; R. H. Harper, Victorian Building Regulations. Summary Tables of the Principal English Building Acts and Model By-laws, 1840-1914 (London, 1985), pp. xi-xxix.

${ }_{59}$ S. D. Chapman, "Working-Class Housing in Nottingham during the Industrial Revolution", in: The History of Working-Class Housing, op. cit., p. 152; J. H. Treble, "Liverpool Working-Class Housing 1801-51", ibid., p. 187. 
continuing surge of urban demand were attractive lures in the conditions of buouyant economic activity. Typically the building firms were small-scale operations. Aspinall has shown that in all the regional subdivisions of England between $70-90 \%$ of firms employed fewer than 10 operatives, and $50 \%$ employed fewer than 5 men, ${ }^{60}$ a conclusion also applicable in Scotland. ${ }^{61}$

Such structural conditions encouraged speculation, usually over-optimistic, or at least a construction level which imperfectly recognized changing local prosperity levels. Even where structural changes in demand were perceived, reverse gear was, for the building industry, difficult to engage. ${ }^{62}$ In particular the need to complete houses in order to achieve a sale and then repay credit advances frequently led to unjustifiably high levels of building well beyond the peak of the local trade cycle. Such overexpansion implied interrupted building until excess stocks in the housing market were cleared, a process which Cairncross has demonstrated could itself produce long cycles in housebuilding production..$^{63}$ It also made for rather tentative builders' responses when local economic conditions did move more favourably, and frenetic building when the trade cycle was actively and consistently on the upward trend. ${ }^{64}$ The reproduction of the cycle was thus assured. More seriously as far as housing was concerned, it was these hectic over-speculative upswings in which the bulk of low-income housing was constructed.$^{65}$ Often in this phase of the cycle rich pickings could be made in land speculation, developing and building - and this offered a measure of

${ }^{60}$ P. J. Aspinall, "The Internal Structure of the Housebuilding Industry in NineteenthCentury Cities", in: The Structure of Nineteenth Century Cities, ed. by J. H. Johnson and C. G. Pooley (London, 1982), pp. 75-105.

${ }_{61}$ R. G. Rodger, "Speculative Builders and the Structure of the Scottish Building Industry, 1860-1914", in: Business History, XX (1979), pp. 226-46.

62 R. C. O. Matthews, The Trade Cycle (Cambridge, 1959), ch. 6, still presents the most concise analysis of building-industry dynamics. See also L. Needleman, The Economics of Housing (London, 1965).

${ }^{63}$ A. K. Cairncross, "The Glasgow Building Industry 1870-1914", in: Review of Economic Studies, II (1934), pp. 1-17.

64 Ibid.

6s Glasgow Corporation, Office of Public Works, Dean of Guild Linings, 1862-1939, show much greater volatility in one- and two-roomed houses than in larger houses. A summary of this is provided in J. Butt, "Working-Class Housing in Glasgow, 1851-1914", in: The History of Working-Class Housing, p. 71; A. Offer, "Ricardo's Paradox and the Movement of Rents in England c. 1870-1910", in: Economic History Review, Second Series, XXXIII (1980), pp. 236-52; R. G. Rodger, "The 'Invisible Hand'. Market Forces, Housing and the Urban Form in Victorian Cities", in: The Pursuit of Urban History, op. cit., pp. 190-211; Glasgow Municipal Commission on the Housing of the Poor, Report (Glasgow, 1904), p. 14. 
support in the leaner years of the cycle. Quick turnover of capital, skimped standards of construction, defective workmanship became commonplace at such a stage of the cycle, the precise point at which the majority of workingclass dwellings were built.

Table 4. Peaks and troughs in British building, 1838-1918

\begin{tabular}{cccccc} 
G r e a t & B ritai & \multicolumn{2}{c}{ L o nd o n } & \multicolumn{2}{c}{ Live r p o o I } \\
Peaks & Troughs & Peaks & Troughs & Peaks & Troughs \\
& & & & 1845 & 1850 \\
& & 1868 & 1873 & 1864 & 1873 \\
1876 & 1886 & 1881 & 1890 & 1878 & 1895 \\
1898 & $1918 ?$ & 1899 & $1918 ?$ & 1903 & $1918 ?$
\end{tabular}

Source: B. Weber, “A New Index of Residential Construction 1838-1950”, in: Scottish Journal of Political Economy, II (1955), p. 113.

The underlying dynamics of the building cycle have been established for some time, as Weber's building indices produced in Table 4 indicate. However, the component parts of the cycle, for example the timing of public building, the different residential strata, are a more recent development. Latterly further research has confirmed the existence of such cycles in the 1850's and 1860's on a more widespread basis than was previously thought to exist. ${ }^{66}$ Though the instability of the housebuilding industry appears to have diminished slightly over the period 1890-1914, its substantial variations were far in excess of those in manufacturing industry. Annual index variations in building output were almost three times greater than overall industrial production. Expressed differently, the instability of the British building industry over a sixty-year period was $168 \%$ above the next most unstable sector, textiles, double that of both the engineering and metallurgical industries, and respectively $261 \%, 345 \%$ and $645 \%$ greater than chemicals, mining and utilities. ${ }^{67}$

${ }^{66}$ P. J. Aspinall, "The Size Structure of the Housebuilding Industry in Victorian Sheffield" [University of Birmingham Centre for Urban and Regional Studies, Working Paper No 49] (1977); J. W. R. Whitehand, "Building Activity and the Intensity of Development at the Urban Fringe. The Case of a London Suburb in the Nineteenth Century", in: Journal of Historical Geography, I (1975), pp. 211-24; comments by Daunton, Whitehand and Rodger, ibid., IV (1978), pp. 175-91, and V (1979), pp. $72-78$. 67 J. A. McKenna and R. G. Rodger, "Control by Coercion. Employers' Associations and the Establishment of Industrial Order in the Building Industry of England and Wales 1860-1914", in: Business History Review, LIX (1985), pp. 203-31. 
These bouts of unprecedented instability in production were partly the consequence of structural conditions inherent in the building industry. They were also attributable in part to the absence of restrictions on the activities of builders. Eventually this combination produced such a degree of instability that it proved unacceptable to both private enterprise and public opinion. Not only did it produce public intervention to control the quality of existing and new housing, and eventually to increase the quantitative supply of working-class housing, it also stimulated a measure of internal reform amongst builders mainly in the shape of collusion to minimize the uncertainty caused by amplitude of fluctuations in production.

\section{IV}

It would be misleading to imply that market forces remained completely unrestricted, or that solutions to the housing problem were not forthcoming. In fact three particular approaches were adopted in the period circa $1850-90$ as a reaction to the laissez-faire phase which ruled to 1850 . That some modifications to non-interventionism existed after mid century should not be seen as a rejection of the liberal philosophy, but as a pragmatic amendment of it, a modification which, based on utilitarian views, extended the liberty of the individual by controlling the encroachment of others.

The first modification came in the realm of public health. Fear of epidemics was a particularly cogent argument for the adoption of restrictive powers upon individuals' activities, and reflected a utilitarian view of social and housing policy which amended the balance of private and social welfare in favour of the latter. It was a housing and environmental crossroads which sparked the public-health movement in the 1850's and 1860's - sanitary inspectors and medical officers appointed by towns, isolation hospitals, slaughtering facilities, control of food markets and so on. ${ }^{68}$ This midcentury willingness to consider social costs and benefits coincided with technical solutions to sewage disposal, water storage and pumping, of which the London Metropolitan Board of Works' sewer building and Glasgow's Loch Katrine reservoir are probably the best-known examples. ${ }^{69}$

68 R. Lambert, Sir John Simon 1816-1904 (London, 1963); Dyos, "The Slums of Victorian London", loc. cit.; F. M. Jones, "The Aesthetic of the Nineteenth-Century Industrial Town", in: The Study of Urban History, ed. by H. J. Dyos (London, 1968), pp. 171-82.

${ }_{69}$ Owen, The Government of Victorian London, op. cit., pp. 47-73; F. Sheppard, London 1808-70. The Infernal Wen (London, 1971); J. D. Marwick, Glasgow - The Water Supply and Various Developments of the City till the close of 1900 (Glasgow, 1901); Allan, "British Urban Redevelopment", loc. cit., p. 603; C. F. Brockington, Public Health in the Nineteenth Century (Edinburgh, 1965), pp. 192-278. 
By the 1880's even the smallest towns had access to continuous supplies of fresh, clean water. The "semi-asphyxiated city" administrative reform and environmental intervention in the Victorian city, albeit reluctantly undertaken.

A second approach was the direct intervention of the municipality and philanthropic interests in the control and provision of housing accommodation..$^{71}$ As early as 1851 Lord Ashley's Common Lodging Houses Act controlled the conditions within public lodging houses, and another act of that year, an adoptive, typically passive piece of legislation, allowed local authorities to increase the overall supply of common lodging houses should they so desire. ${ }^{72}$ While this type of legislation dealt essentially with the homeless, another type of municipal restraint, the "ticketed tenement" system, was developed in Glasgow and was concerned with working-class housing. ${ }^{73}$ Maximum occupancy levels were proscribed according to the cubic capacity of the accommodation, and fixed or "ticketed" to the external door of houses. ${ }^{74}$ Enforcement entailed night visits - some 40,000 of them per annum in the 1880 's -, but the low number of infractions ( $4.9 \%$ ) reflected both the residents' ability to anticipate the inspection and temporarily move out, and the authorities' acknowledgement that alternative accommodation and the capability to pay fines was extremely limited..$^{75}$ Poverty clearly was central to the problem of overcrowding, and the need to maintain aggregate household income often meant the sacrifice of domestic space either to lodgers or to ageing family members.

The central focus of this municipal housing activity remained essentially sanitary, as exemplified in the Artisans' and Labourers' Dwellings (Torrens's) Act, 1868, and the Labourers' Dwellings Improvements (Cross's)

70 Public Health Administration in Glasgow, ed. by A. K. Chalmers (Glasgow, 1905), p. 142. These collected papers of Glasgow MOH Dr J. B. Russell provide a useful insight into contemporary professional views regarding health and housing.

${ }^{7}$ Gauldie, Cruel Habitations, op. cit., pp. 213-35; Tarn, Five Per Cent Philanthropy, op. cit.

72 Gauldie, Cruel Habitations, pp. 239-59, gives an excellent brief account of the acts.

${ }^{73}$ J. B. Russell, "On the Ticketed Houses of Glasgow", reprinted in Public Health Administration, op. cit., pp. 206-28; Butt, "Working-Class Housing in Glasgow", loc. cit., pp. 68-69.

74 Glasgow Municipal Commission, Report, op. cit., p. 2; Glasgow Police Act, 1866 [29 \& 30 Vict., c. 273], Section 378.

75 Royal Commission, Vol. V, Minutes of Evidence [PP, 1884-85, XXXI, C. 4409-I], Appendix C; Glasgow Municipal Commission, Report, p. 8; furthermore only those cases where overcrowding was $33 \%$ above the standard allowed on the "ticket" were taken to court, ibid., p. 4. 
Act, $1875 .{ }^{76}$ The local authority was empowered to require owners to improve individual properties under the 1868 legislation; under the 1875 act they could deal with larger insanitary areas and might require new buildings to replace any houses demolished. In practical terms the 1868 act remained a dead letter, the 1875 act was implemented in only a handful of boroughs outside London, and neither had any force in Scots law. Such initiatives, doctrinally determined by minimal public intervention, yet concerned for the moral and spiritual welfare of urban dwellers, produced a paradox in policy. Their emphasis on slum clearance, transparently necessary by mid century, was undertaken without sufficient regard to the provision of new housing stock; qualitative improvement was seen as unconnected to quantitative provision. ${ }^{77}$ It was not the place of the local authority, so it was argued, to construct houses and so invade the preserve of private enterprise. ${ }^{78}$

This resolute objection to actually building houses was to some extent present in the endeavours of philanthropic organizations. Pauperism, defective living conditions and related social evils were interpreted as a character deficiency which could be overcome by teaching, example and exposure to sound principles of household economy. The emphasis on individualism as the dominant social value dictated that unless and until slum dwellers themselves recognized the error of their ways, until their character was reformed, then transplanting them to alternative accommodation would only reduce that property to the condition of other slums. Or, as the language of an official enquiry put it, pigs created the sty; the sty did not create the pig. ${ }^{79}$ Hence the futility of public building until tenants' behaviour was reformed. An extended adherence to laissez-faire principles in relation to housing problems was therefore an integral part of a long-run strategy to reform society. Short cuts, such as municipal housebuilding,

${ }^{76}$ For an account of these acts see Gauldie, Cruel Habitations, pp. 265-81. See also Royal Commission Report; J. A. Yelling, Slums and Slum Clearance in Victorian London (London, 1986); S. M. Gaskell, Model Housing: From the Great Exhibition to the Festival of Britain (London, 1986).

$\pi$ A. Briggs, "The Victorian City: Quantity and Quality”, in: Victorian Studies, XI, pp. 711-30.

78 The objection to municipal building, except in the case of the homeless and disadvantaged, was present in the Royal Commission Report. Even in 1890 quantitative additions to housing were discretionary. By 1904 the Glasgow Municipal Commission acknowledged, as the London County Council had for a few years, that private enterprise could not be relied upon to provide housing for the lowest-paid.

79 J. B. Brown, "The Pig or the Sty: Drink and Poverty in Late Victorian England", in: International Review of Social History, XVIII, pp. 380-95. See also O. Hill, Homes of the London Poor (London, 1875), p. 7. 
would be only effective in the short term; slum conditions would re-appear unless character deficiencies such as indolence were exorcized. ${ }^{80}$

Philanthropic demonstrations, for example the Society for Improving the Condition of the Labouring Classes (founded 1844), Metropolitan Association for Improving the Condition of the Industrious Classes (1841), Peabody Trust (1862), the Improved Industrial Dwellings Company (1863), Artizans', Labourers' and General Dwellings Company (1867), were concentrated in London, though mutual co-operative and philanthropic efforts in many other boroughs also attempted to show by example how well-run housing schemes could alter of residents' living conditions. ${ }^{81}$ These agencies introduced design improvements, property superintendents and enlisted unpaid social workers to give guidance to residents. Occasionally the Charity Organisation Society attempted to co-ordinate these efforts but for the most part they remained independent, isolated attempts to grapple with an immense problem.

Such projects achieved much for individual tenants. ${ }^{82}$ Aggregatively they accomplished very little. Strained financially, such endeavours were limited to housing those who could keep up regular rental payments; artisans and the more regularly employed labouring class were therefore the occupants of such philanthropic housing. The desire to demonstrate the viability of working-class housebuilding drove many of these organizations to aim for a commercially competitive $5 \%$ return on capital, another powerful force for admitting residents capable of maintaining regular rentals. Indeed these charitable attempts may have intensified the housing problem, first by deflecting concern from the real housing crisis, that of the insufficient supply of accommodation for the unskilled labouring population on irregular wages, and second by giving an extended run to the concept of moral reform. A third influence, probably due more to later local-authority housebuilding than to philanthropic activities, was to disincline the private sector to build working-class houses at the lower end of the spectrum for fear that rents, building standards and other operational considerations would be specified either by byelaws or by general practice, thus constraining their independence of action. ${ }^{83}$

Voluntary housing efforts were unsuccessful for the simple reason that it

80 Royal Commission, First Report, pp. 14-15.

81 For an account of mid-century philanthropic organizations, see Tarn, Five Per Cent Philanthropy, pp. 15-66.

82 Wohl, The Eternal Slum, pp. 141-78; G. Best, Temporal Pillars (Cambridge, 1964); J. White, Rothschild Buildings (London, 1980).

83 Glasgow Municipal Commission, Report, and evidence of Binnie, q. 6555, McKellar, q. 10936, Mann, q. 8488, and Watson, q. 11247. 
was beyond the societies' resources to help ${ }^{84}$ with the scale of the problem, and, consequently, "however worthy they might be, or however piteous their case", ${ }^{85}$ the poorest stratum was wholly dependent upon the accommodation produced and rented by private builders and landlords. Even in 1914 , after a decade of more active municipal housebuilding, $99 \%$ of house construction was undertaken by the private sector. ${ }^{86}$ Perhaps more significantly, by 1912 only 15,000 or $0.25 \%$ of all dwellings under $£ 20$ annual value - that is at the level compatible with working-class incomes - had been built by local authorities and philanthropic efforts.$^{87}$ The contribution of public and philanthropic interests, while laudable, were inconsequential in the overall attack upon housing problems.

The third solution to the housing problem was to leave it alone. Indeed it was to leave it behind. Suburban dwelling had a lengthy pedigree, but from mid century, and lemming-like from the passage of the Tramways Act in 1870 , the middle class sought isolation from the housing and environmental hazards of the city centre in a suburban setting. ${ }^{88}$ Technological solutions to urban mobility - successively suburban railways, horse and electric omnibuses and trams - facilitated this flight from hostile living conditions, allowing the middle class to avoid the housing problem and thus escape any need to confront it or solve it ${ }^{89}$ As the President of the Local Government Board, John Burns, observed during a ceremony to lay the foundation stone of the Bevington Street Housing Scheme in Liverpool, as late as 1910,

I want to talk if I may to the people who live at Sefton Park and Wavertree,

84 B. B. Gilbert, The Evolution of National Insurance in Britain (London, 1966), p. 28.

85 Ibid.

${ }^{86}$ R. Reiss, The New Housing Handbook (London, 1924), p. 15; S. D. Chapman,

"Introduction", in: The History of Working-Class Housing, pp. 11-12.

87 42nd Annual Report of the Local Government Board, 1912-13 [Cd 6981].

88 H. J. Dyos and D. A. Reeder, "Slums and Suburbs", in: The Victorian City, I, pp. 359-86; H. J. Dyos, "Urbanity and Suburbanity" (inaugural lecture), in Exploring the Urban Past. Essays in Urban History, ed. by D. Cannadine and D. Reeder (Cambridge, 1982), pp. 19-36; D. A. Reeder, "A Theatre of Suburbs: Some Patterns of Development in West London, 1801-1911", in: The Study of Urban History, op. cit., pp. 253-71; Middle-Class Housing in Britain, ed. by M. A. Simpson and T. H. Lloyd (Newton Abbot, 1977); F. M. L. Thompson, Hampstead: Building a Borough 1650-1964 (London, 1974); W. D. Rubinstein, "The Victorian Middle Classes: Wealth, Occupation and Geography", in: Economic History Review, Second Series, XXX (1977), pp. 602-23.

${ }^{89}$ H. J. Dyos, "Railways and Housing in Victorian London. Rustic Townsmen", in: Journal of Transport History, II (1955), pp. 90-100; id. and D. H. Aldcroft, British Transport: An Economic History from the Seventeenth Century to the Twentieth (London, 1969); A. D. Ochojna, "Lines of Class Distinction. An Economic and Social History of the British Tramcar with Special Reference to Edinburgh and Glasgow" (unpublished Edinburgh Ph.D. thesis, 1974). 
and to those who live across the river - who are in Liverpool when it suits them and out of it when it pleases them. ${ }^{90}$

Referring to the five times greater tuberculosis rate in the Exchange compared to the Sefton Park divisions, Burns drew attention to middleclass responsibilities: "The measure of your immunity from this scourge ought to be the standard of your benevolent help to the poor people." 91 Even here it seems that in 1910 the virtue of private initiatives to combat the housing crisis was being extolled. Suburbanization allowed the abdication of civic responsibility an extended run, and only when confronted by wider issues - national efficiency and security, enfranchisement and political representation of labour, and the problem of social control in a moral vacuum - would the middle class address the deepening crisis.

While Burns's philosophy demonstrated the longevity of Victorian values in relation to housing, the extended ideological experiment which the New Poor Law represented was undergoing some challenges, if few immediate alterations, in the 1880's. Reformation of character as the cornerstone of social amelioration had been given a lengthy trial. Little perceptible improvement had resulted. Specific cases of hostile housing conditions had been cleared or contained under local improvement acts and building byelaws. But statistical indicators of social conditions, for example, the persons-to-house ratio showed a worsening trend until 1881 , and the infant mortality rate remained obstinately static until the twentieth century.

A misfiring in the national economy, the rise of imperial Germany with its programme of limited social insurance, and the rise of labour both as a potential electoral force and as a wage-bargaining power in spectacular strikes at the end of the 1880's signalled the impending curtailment of an entrepreneurial free rein. The years immediately preceding the turn of the century posed a question-mark against the existing status quo of British capitalism, and in particular the income distribution and social pattern achieved. ${ }^{92}$ It further called into question her abilities to discharge imperial

90 City of Liverpool, Artizans' and Labourers' Dwellings and Insanitary Property: Report of the Housing Committee (Liverpool, 1913), p. 26.

91 Ibid.

92 J. R. Hay, The Development of the British Welfare State, 1880-1975 (London, 1978), contains extracts from a number of pressure groups, social reformers and prominent individuals. See also id., Origins of the Liberal Welfare Reforms 1906-14 (London, 1975); P. Thane, "Introduction", in: The Origins of British Social Policy, ed. by id. (London, 1978), pp. 18-19, notes "the international change in attitudes to social welfare from the 1880s"; D. Fraser, The Evolution of the British Welfare State (London, 1973). 
responsibilities and her international credibility when the distributional implications of industrialization were clearly skewed in British society itself. The imagined dialogue between missionary and savage made the point, devastatingly.

Savage: Is it true, sir, that in the country you come from, low people live by tens of thousands in such a way that it is considered almost impossible to teach them that which you come out here thousands of miles to teach me? Missionary: Yes, [people] live in filth and wretchedness and live and sleep together without regard to age or sex, and quite contrary to the precepts of the Gospel I am now come to teach you. ${ }^{93}$

The duplicity of standards was transparent. As the writer commented, "we must either realize our religion and its duties", or give it up; "our religion as well as our social institutions are on trial in this matter." 94

The challenge to the imperial capability was further dented ten years later in the Boer War, both because of strategic obsolescence in a campaign against a minor military force and because of physical decrepitude amongst significant proportions of British recruits rejected as physically unsuitable for active service. ${ }^{95}$ At the Manchester recruiting depot during 1899, 8,000 of the 12,000 presenting themselves were rejected for physical reasons, and only 1,200 were actually thought to be capable of military service. Rowntree, in surveying the recruiting stations in York, Leeds and Sheffield, discovered the army had immediately rejected $26 \%$ as unfit, and had had to amend regulations to consider another $29 \%$. Articles and letters appeared in The Times entitled "National Deterioration", and the article by Sidney Webb was headed "Physical Degeneracy or Race Suicide". The implications for national security were ominous. The challenge to existing housing and social philosophy evident in the 1880's and 1890's was therefore more vigorously aired in the 1900's. As a result more active localauthority efforts to add to the stock of working-class housing, partly with greater central funding from the Local Government Board, were undertaken, London County Council being one of the most active in this respect. ${ }^{96}$

But the most emphatic and telling challenge to the prevailing Victorian approach to housing was directed at its central propositions: the attack

93 W. Rendle, London Vestries and their Sanitary Work (London, 1865), pp. 24-26, quoted in Wohl, The Eternal Slum, p. 51.

94 Ibid.

95 Report of the Inter-Departmental Committee on Physical Deterioration [PP, 1904, XXII, Cd 2175]; B. B. Gilbert, "Health and Politics: The British Physical Deterioration Report of 1904", in: Bulletin of the History of Medicine, XXXIX (1965), pp. 143-53. \% W. Thompson, Housing Up-to-date, pp. 37-60. 
concentrated upon the assumptions beneath the outlook on housing. Doubts were expressed by social and sanitary reformers, medical officers of health, evangelical and the more conservative clergy that the scale of the housing crisis and related social ills such as overcrowding, insobriety and moral degeneration could be combatted by reluctant public intervention and a reliance on character improvement. ${ }^{97}$ The churches, conscious of their "ill-success" and "unattractiveness" to the labouring classes, recognized as early as 1851 that pious hopes for moral elevation were themselves insufficient; in fact, so concerned were they in mid century about the Christless society that they recommended housing reform as a precondition for a return to Christianity. ${ }^{98}$ The concern for irreligious and immoral behavior sprang partly from the genuine desire for the spiritual redemption of the working class, from the sins associated with their living conditions. It owed some allegiance, too, to the desire to appease the collective middle-class conscience in relation to this seemingly intractable problem. But it was also associated with the spectre of social control.$^{99}$ Indeed central to the tenets of Octavia Hill, Shaftesbury and others was the role of the home as an agent of social stability. ${ }^{100}$

According to Shaftesbury

There can be no security to society, no honour, no prosperity, no dignity at home, no nobleness of attitude towards foreign nations, unless the strength of the people rests upon the purity and firmness of the domestic system. Schools are but auxiliaries. At home the principles of subordination are first implanted and the man is trained to be a good citizen. ${ }^{101}$

Thus the Victorian failure to adequately house the lower-income groups was by the 1880 's causing sufficient alarm about morality that it threatened to upset prevailing value systems. Such nervousness regarding the status

97 Wohl, The Eternal Slum, pp. 221-49, discusses the changing attitude to laissez-faire; also Gauldie, Cruel Habitations, pp. 285-87; The Times, 16, 20, 22, 24, 27 and 30 November, 1, 18, 22 and 27 December 1883, carried articles describing and commenting on working-class housing and the need for a new approach; other newspapers did likewise.

98 Report of the Select Committee on the Deficiency of Means of Spiritual Instruction [... ] in the Metropolis and in Other Populous Districts in England and Wales, Especially in Mining and Manufacturing Districts [PP, 1857-58, IX]. See also Report of the Ritual Commission [PP, 1867, XX; 1867-68, XXVIII].

99 W. Logan, The Moral Statistics of Glasgow (Glasgow, 1849).

100 Best, Temporal Pillars, op. cit.; Owen, English Philanthropy, op. cit., A. S. Wohl, "Octavia Hill and the Homes of the London Poor", in: Journal of British Studies, X (1971), pp. 105-31.

101 Wohl, The Eternal Slum, p. 50; id., "The Bitter Cry of Outcast London", in: International Review of Social History, XIII (1968), pp. 189-245. 
quo induced the sacrifice of non-interventionism by public authorities in the housing arena. In inaugurating a local-authority housing project in 1910 the President of the Local Government Board revealed that such departures were a means of improving personal responsibility, enhancing citizenship: "a good home developed certain qualities [. . . ] necessary in these days, [. . . ] and a good home resisted pauperism, diminished dependence, made for sobriety, and [ . . . ] gave character to the children in a way that nothing else did." 102 Arguably, the principle and the annual cost were a small price to pay for social stability.

The last two decades of the nineteenth century, therefore, contained a frontal assault on the central propositions of Victorian poverty in general, and housing in particular. In the context of extensions in the franchise and increasingly powerful trade unions, the recognition, highlighted by Mearns and others in the 1880 's, that the moral crusade had failed stimulated considerable anxiety amongst late Victorians. Personal endeavour and the example and exhortations of charitable and philanthropic organizations had had no effect on the scale of the housing crisis. The recognition of this in the 1880 's presented a new prospect: that the housing crisis and attendant problems of social control could not be contained without challenging the traditional organization of society, without some degree of compulsory income re-distribution, possibly by taxation, and without the apparatus of state intervention and public administration.

\section{VI}

With this climacteric of the 1880's in mind, what was achieved by interventionism before 1914? Very little, must be the unambiguous answer. The continuation, in many cases the intensification of overcrowding rates, the disease, lunacy and suppressed-child-growth rates cited in Tables 1-3 confirm the size of the problem and the marginal impact made upon it before World War I. The Royal Commission on the Housing of the Working Classes, 1884-85, had officially aired the problem and a lukewarm legislative proposal, not exactly rushed to the statute book, became the Housing of the Working Classes Act, $1890 .{ }^{103}$ Part III of this act allowed local authorities to initiate for the first time housing proposals of their own. A great deal has been made of this clause facilitating new building as opposed to the previous slum-clearance policy. The act was, however, adoptive, not compulsory, though by allowing without requiring municipalities to build 
working-class houses themselves the 1890 legislation acted as a bridge between the voluntarism of the Victorian age and the compulsion of the twentieth century. In 1909 a more glamourously entitled Town Planning Act $^{104}$ gave the semblance of structured housing development, utilizing garden-city and utopian planning ideals which had also developed since the 1880 's, as for example at Letchworth, Port Sunlight and Bournville, but this had achieved little by $1914 .{ }^{105}$

Only gradually was the framework of housing intervention being developed. Even more slowly was the supply of houses for labourers being increased. London County Council was the most active in the expansion of its housing function, and by 1912 had housed 54,000 people in 9,272 dwellings scattered on 19 principal sites. ${ }^{106}$ Even here, however, as the Appendix shows, the occupational composition of London County Council tenants suggests that municipal housebuilding still favoured the skilled worker, for whom the private sector had always been able to construct adequate houses and obtain a commercial return. The Liverpool City Council, the next most active authority, built 2,721 dwellings by $1913,85 \%$ of them following the passage of the 1890 legislation. ${ }^{107}$ But whereas these and other councils in Edinburgh, Glasgow, Birmingham, Sheffield, Manchester, Dublin and several London boroughs were active in building block and cottage dwellings for workers, by 1907 only 160 out of 803 urban councils $(20 \%)$ had done anything under the terms of the act. ${ }^{108}$

Interestingly, and providing some confirmation of the artisan rather than unskilled composition of municipal tenants, the average net return on London County Council housing on schemes undertaken before 1906 was $3.6 \% .{ }^{109}$ Glasgow City Council obtained a 3.06\% net return over the years 1897-1902; Liverpool 2.67\%. On all municipal housebuilding in Britain undertaken before 1907 the average net return was $3.29 \%$ on the accumulated capital investment of $£ 3.66$ million. ${ }^{110}$ Clearly, this reflected a lesser concentration on artisans than under the philanthropic projects, but it still represented a not unacceptable rate of return in relation to, say, consols before 1914.

1049 Edw. VII, c. 44.

${ }^{105}$ G. E. Cherry, The Evolution of British Town Planning (London, 1974), pp. 6-55.

106 London County Council, Housing of the Working Classes in London (London, 1913), Appendix IX, p. 157. The census of the preceeding year enumerated 758,000 as living in unacceptable housing conditions.

107 City of Liverpool, Report of the Housing Committee for 1913 (Liverpool, 1914), pp. 73-74.

108 Thompson, Housing Up-to-date, p. 6.

109 Ibid., p. 72.

110 Ibid., pp. 100, 123. 
More seriously as far as the increase in overall supply of housing was concerned, the extension of public intervention had a significant impact on the building industry. Building byelaws, belatedly introduced, were, it was argued, unduly demanding in structural requirements and obsolescent in relation to technological change, limiting the uses of concrete, steel-framed building and other potentially cost-reducing techniques. ${ }^{111}$ More ominously, the local authority as builder and landlord through lower interest rates and land acquisitions could undercut the private sector costs of production. ${ }^{112}$ Municipal rents reflected this, thereby imposing a floor upon all rents which was sufficiently low to both deter investors and increase landlords' problems of property management - arrears, maintenance and repairs, eviction, letting contracts and the bailiff. ${ }^{113}$ Thus landlords' margins, already eroded in the late-Victorian period, were insufficiently attractive after the boom of the 1900's to expand the supply of private lettings and was reflected in a $40 \%$ decline in the capital value of houses during the years 1902-12. ${ }^{114}$ For workers the tendency was for rent to swallow an increasing proportion of income as the nineteenth century closed, and thereafter they discovered that their obsolete homes often compared unfavourably both in terms of price and quality compared to local-authority properties.

These conditions, compounded by attractive alternative investment outlets, including gilt-edged securities, produced a haemorrhaging in the overall supply of new housebuilding nationally after 1905, although there were regional variations. ${ }^{115}$ Furthermore, while the councils renovated some defective housing at the end of the nineteenth century and added to the volume of new building after 1890 , simultaneously they demolished existing accommodation for improvement purposes - street widening, electricity-generating stations, tram depots, tunnels and other transport

111 Glasgow Municipal Commission, Report, p. 17; E. Gauldie, Cruel Habitations, pp. $167,177$.

112 Glasgow Municipal Commission, Report, pp. 15-16, and evidence of Binnie, qq. 6415-7019, and Eadie, qq. 7190-7358.

113 Ibid.

114 A. Offer, Property and Politics 1870-1914. Landownership, Law, Ideology and Urban Development in England (Cambridge, 1981), pp. 268, 279.

115 A. K. Cairncross, Home and Foreign Investment 1870-1913 (Cambridge, 1953), gives a comprehensive account of these. See also P. L. Cottrell, British Overseas Investment in the Nineteenth Century (London, 1975), pp. 27-28; S. B. Saul, "Housebuilding in England 1890-1914", in: Economic History Review, Second Series, XV (1962), pp. 11937; J. P. Lewis, Building Cycles and Britain's Growth (London, 1965). 
improvements. ${ }^{116}$ Replacement accommodation was at best delayed, sometimes overlooked and occasionally re-sited in peripheral districts, though such failings were less valid in the case of the London County Council, where between 1884 and 190212,504 people were housed as compared with 12,244 displaced through improvement schemes. ${ }^{117}$

Thus precisely the haemorrhaging of lower-working-class housing supply, which public intervention was designed to staunch, was intensified by that same intervention through its marketplace impact on the decisions of private landlords and builders. Within the building industry the rise of organized labour, development of compulsory arbitration and conciliation, disproportionately rising labour to total costs of construction, and the rise of the Labour Party on city councils influencing the award of building contracts and strengthening the position of direct municipal building departments were formidable influences which further persuaded private builders to quit the lower echelons of the housing market. ${ }^{118}$ In seeking safer, more predictable sections of the market, and in particular the housing of the suburbanizing middle class, the building industry, too, may have demonstrated the business conservatism of which much of the British manufacturing industry has been accused in the years before World War I. ${ }^{119}$ Alternatively, they may simply have made an astute appraisal of risk and return, and as a consequence opted out of the market for working-class housing.

\section{VII}

The caution with which builders approached low-income housebuilding from about 1880 was compounded by changing circumstances amongst property interests. Landlords' problems centred on escalating tax burdens, which fell disproportionately on property. ${ }^{120}$ These fiscal pressures were induced by mounting municipal expenditures resulting from expanded civic

116 E. Hopkins, "Working-Class Housing in the Smaller Industrial Town in the Nineteenth Century: Stourbridge - A Case Study", in: Midland History, IV (1978), pp. 23054; Smith, "Planning as Environmental Improvement", loc. cit.

117 Housing of the Working Classes in London, Appendix p. VI, p. 152.

118 R. Price, Masters, Unions and Men. Work Control in Building and the Rise of Labour, 1830-1914 (Cambridge, 1980); R. G. Rodger, "Instability and Insecurity. Employers' Responses and the Search for Industrial Control in the Building Industry of England and Wales, 1860-1914", paper presented to the Economic and Business Historical Society meeting, San Antonio, April 1983.

${ }_{119}$ P. L. Payne, British Entrepreneurship in the Nineteenth Century (London, 1974), provides an extensive bibliography on this issue.

${ }_{120}$ Offer, Property and Politics, op. cit., pp. 221-313. 
responsibilities statutorily imposed in the last third of the nineteenth century. Education, museums and libraries, baths and washhouses, transport, utilities, isolation of infectious diseases, slaughterhouses, sanitary and building control and many other areas of municipal supervision required substantial recurrent annual and capital outlays. ${ }^{121}$ Overall local-government expenditure rose by over $300 \%$ during the years $1870-1910 .{ }^{122}$ Property, the basis of local revenue, felt the increased burden acutely despite vigourous opposition based on claims of victimization of housing interests, favouritism to land hoarding and speculation, and the inevitable additions to working-class rents due to increased property charges. The average national rate in the pound doubled between 1885 and 1914, when for the most part general prices were falling appreciably. ${ }^{123}$ Obligated by statute law, town councils had limited scope for financial manoeuvre, and the squeeze on profitability resulting from increased property taxes hastened landlords to the conclusion that property management for lowincome groups was unattractive. This fiscal assessment reinforced existing trends in the housebuilding sector as investors and property managers eventually recognized that working-class housing was a marginal commercial operation, and the $40 \%$ plunge in capital values of London property during the years 1902-12 was the logical result of this appraisal. The demise of private landlords dated from circa 1900 , not from wartime rent controls in 1915 or subsidized council housing in $1919 .{ }^{124}$

The fiscal pressure experienced by landlords was increasingly felt by tenants. Not only were higher property taxes passed on in weekly rentals, but management strategies more than ever concentrated on reducing rent arrears, minimizing vacancy rates, prompt evictions, and attempts to sequestrate tenants' possessions to compensate for non-payment of rents. ${ }^{125}$ The vortex of profitability inevitably prompted intensified conflict between landlords and tenants, as both sides of the rent bargain sought to obtain and defend a marginal advantage. In a sense tension in property relations had

121 J. R. Kellett, "Municipal Socialism, Enterprise and Trading in the Victorian City", in: Urban History Yearbook, 1978, pp. 35-45; E. P. Hennock, "Finance and Politics in Urban Local Government in England 1835-1900", in: Historical Journal, VI (1963), pp. 212-25; M. E. Falkus, "The Development of Municipal Trading in the Victorian City", in: Business History, XIX (1977), pp. 134-61.

122 Mitchell and Deane, Abstract of British Historical Statistics, op. cit., p. 418; Feinstein, Statistical Tables, op. cit., T 132.

123 P. J. Waller, Town, City and Nation. England 1850-1914 (Oxford, 1983), p. 257.

124 Offer, Property and Politics, pp. 268, 279, 405; Daunton, House and Home, op. cit., p. 295.

125 D. Englander, Landlord and Tenant in Urban Britain 1838-1918 (Oxford, 1983), pp. 3-81; Daunton, House and Home, pp. 90-178. 
been evident since the Small Tenements Recovery Act 1838 enabled landlords to arbitrarily re-possess accommodation without recourse to the courts. Counterbalancing this sweeping power, the tenants' armoury including flitting without payment of rent, wilful damage, and the sale of fixtures, sanctions sufficient to keep the abuse of re-possession powers at bay. But the concern for profitability from the 1870 's led to a new crescendo of landlord-tenant conflict, as expressed in revitalized political action groups such as ratepayers' and tenants' associations, the Workmen's National Housing Council (1898), rent strikes (1911-13) in English boroughs and, in Scotland at least, escalating evictions. ${ }^{126}$ For example, in Glasgow evictions rose from about 3,2000 per annum in the 1870's to over 20,000 by 1906 ; landlords' common-law actions to recover rent arrears through the forced sales of tenants' possessions more than doubled 1899 to $1910 .{ }^{127}$ These were manifestations of intensified landlord-tenant conflict, founded on a cumulative squeeze on profitability originating from additional fitments and structural standards arising from building byelaws, higher taxes, and landlords' obligations to comply with an increasingly complex code of municipal regulations and procedures. ${ }^{128}$

Nor did the politics of housing, circa 1880-1914, offer the prospect of relief to either landlords or tenants. The Conservative and Liberal parties concurred on the inequities of property taxes, but neither made practical headway with the issue. ${ }^{129}$ The Conservatives eventually favoured increasing block grants from the Treasury to relieve local financial difficulties, but essentially did not address the problem of the unequal impact of the rates on property-owners. The Liberals, by contrast, sought to switch the burden of property taxes from houses to the land, along the lines advocated by Henry George in Poverty and Progress (1881), where appreciating urban site values were subject to a "betterment" tax which, in the manner of capital-gains taxation, removed the "unearned increment" achieved by the combined impact of population pressure and municipal rather than private improvements. The prospect of appreciating site values encouraged land hoarding, diminished supplies of land for housing, raised land prices and

126 Englander, ibid.; S. Damer, "State, Class and Housing: Glasgow 1885-1919”, in: Housing, Social Policy and the State, ed. by J. Melling (London, 1980), pp. 73-112; J. Melling, Rent Strikes. Peoples' Struggle for Housing in West Scotland 1890-1916 (Edinburgh, 1983), p. 19.

127 Englander, Landlord and Tenant, op. cit., p. 42.

128 N. Morgan and M. J. Daunton, "Landlords in Glasgow. A Study of 1900", in: Business History, XXV (1983), pp. 264-86.

${ }^{129}$ Offer, Property and Politics, pp. 163-66; Daunton, House and Home, pp. 222-33. 
rents, and contributed to the creation and retention of slums and overcrowding. ${ }^{130}$ This housing-reform and income-re-distribution proposal offered an integrated assault on working-class housing problems, but its very audaciousness proved a political liability, challenging established landed interests and thus weakening support for the "single tax". Lloyd George incorporated land taxation in the "Peoples' Budget" proposals of 1909 , and again resurrected them in 1914 without success. ${ }^{131}$ To a certain extent, then, it was the persistence of working-class housing problems interconnected with the land question which ultimately wrecked the radical administrative reforms and re-distributive intent of Liberals in the early twentieth century, and consigned Liberals, landlords and local-taxation reform to the political scrap-heap.

\section{VIII}

Few historical solutions are "inevitable"; mainly they represent the conjuncture of specific factors to produce a unique temporal outcome. Council housebuilding was no exception. It was not pre-ordained or inevitable. ${ }^{132}$ But in 1914, with the political initiative towards land, property taxation and housing reform in the wilderness, building for low-income families virtually stalled after 1905, impressive real-wage gains of $1.5 \%$ per annum, 1860-95, encountering a prolonged plateau, 1895-1914, and co-operative, housingassociation or other self-help approaches at a standstill and unlikely to yield much short-term impact on the scale of urban housing problems, municipal housing represented a realistic approach. Moreover, the ideological purity of laissez-faire had long since been impeached through community concern for and control over public health.

Conceivably Daunton and Thompson are correct to argue ${ }^{133}$ that the Edwardian period was a cyclical lull, that something would turn up in due course to address working-class housing problems, and that Continental

130 Offer, Property and Politics, p. 186; D. A. Reeder, "The Politics of Urban Leaseholds in Late Victorian England", in: International Review of Social History, VI (1961), pp. 413-30.

131 B. K. Murray, "The Politics of the 'People's Budget' ", in: Historical Journal, XVI (1973), pp. 555-70; B. B. Gilbert, "David Lloyd George, Land, the Budget and Social Reform", in: American Historical Review, LXXXI (1976), pp. 1058-64; id., "David Lloyd George, the Reform of British Landholding and the Budget of 1914", in: Historical Journal, XXI (1978), pp. 117-41.

132 Daunton, House and Home, pp. 1-4, 286-307, provides an excellent summary of the arguments.

${ }^{133}$ F. M. L. Thompson, "How They Lived Then", in: Times Literary Supplement, 2 August 1974, p. 823, quoted in Daunton, House and Home, p. 2. 
Europe developed solutions to similar conditions without such reliance on municipal housing. ${ }^{134}$ Though such a view is itself predicated on a comfortable liberal ideology, there is cause to take it seriously. It was A. J. Balfour who claimed that "Social legislation [. . . ] is not merely to be distinguished from Socialist legislation but it is its most direct opposite and its most effective antidote." 135 Council housing, thus interpreted, reasserted the status quo with employers retaining the upper hand; intervention in the residential sector ultimately facilitated the continued operation of an "invisible hand" and laissez-faire principles by providing a temporary prop to correct the unacceptable distributional implications of Victorian capitalism. Casual employment, irregular wages and a role as shock-absorbers caused by the vicissitudes of trade-cycle dynamics consigned significant proportions of the Victorian working class to primary poverty, obliging them to inhabit defective houses with serious health and environmental implications. So sanitary improvements, slum clearance and, ultimately, council housebuilding and management represented an ideological continuum, geared to the provision of a pool of labour for British industry. Successively, and successfully, they represented marginal ideological concessions in defence of the prevailing value system. ${ }^{136}$

In addition, the ascendant star of labour, both party and movement, was perceived as a threat to the free-market precepts of the Victorian age, and may also have been a target for social reformers, viz., to defuse potential militancy, and diffuse it before it had become fully effective and permanently upset the balance of power between labour and capital in British industry. Businessmen were far from absent in the campaign for housing reform in the thirty years before 1914, and, with a question-mark over national efficiency and defence, the issue of the reproduction of labour to boost both production and recruitment cannot be ignored. ${ }^{137}$ Victorian

${ }^{134}$ Daunton, House and Home, p. 293.

${ }_{135}$ Fraser, The Evolution of the British Welfare State, op. cit., p. 129.

136 J. R. Hay, "Employers' Attitudes to Social Policy and the Concept of 'Social Control', 1900-1920", in: The Origins of British Social Policy, op. cit. , pp. 107-25; J. Brown, "Social Control and the Modernisation of Social Policy, 1890-1929", ibid., pp. 126-46; J. Melling, "Employers, Industrial Housing and the Evolution of Company Welfare Policies in Britain's Heavy Industry: West Scotland, 1870-1920", in: International Review of Social History, XXVI (1981), pp. 255-301; Hay, The Development of the British Welfare State, op. cit., pp. 4-7, 32-41, demonstrates employers' interest in sustaining the quality of labour available to British industry.

137 J. Foster, "How Imperial London Preserved Its Slums", in: International Journal of Urban and Regional Research, III (1979), pp. 93-114; D. Rose, "Accumulation Versus Reproduction in the Inner City. The Recurrent Crisis of London Revisited", in: Urbanization and Urban Planning in Capitalist Society, ed. by M. Dear and A. J. Scott (London, 1981), pp. 339-81. 
housing, "a crucial element in the reproduction of labour power", 138 seriously prejudiced the productive capabilities of industry, and intervention in the housing market as a temporary corrective was ideologically acceptable from the stance of improving the quality and quantity of the workforce. Indeed, local authorities as representatives of the middle class defended non-intervention at their peril. Their immediate mid-century peril was epidemic disease and moral contamination; towards the end of the Victorian age it was a deep-seated unease about the achievements and direction of economic progress, and its impact on the deepening social and moral malaise; after World War I it was the stability of government itself which was imperilled. ${ }^{139}$ Even then ideological commitment to laissez-faire was relinquished reluctantly. Only gradually recognized in the Victorian period, the interconnections between housing conditions and the complete individual, between individual physical and mental well-being, and between national economic and military strength were cryptically summarized on the dustjacket of the book The Home I Want. Published in 1919, it depicted a demobilized soldier proclaiming: "You cannot get an A1 population out of $\mathrm{C} 3$ homes." 140

138 A. Hooper, "The Political Economy of Housing in Britain", in: International Journal of Urban and Regional Research, II (1978), p. 182. This type of interpretation is most forcibly presented by M. Castells, The Urban Question. A Marxist Approach (London, 1976), and in C. G. Pickvance, "Housing. Reproduction of Capital and Reproduction of Labour Power. Some Recent French Work", in: Antipode, VIII (1976), p. 58-68.

139 M. Swenarton, Homes fit for Heroes. The Politics and Architecture of Early State Housing in Britain (London, 1981), pp. 78, 130; P. K. Clyne, "Re-opening the Case of the Lloyd George Coalition and the Post War Economic Transition", in: Journal of British Studies, X (1970), pp. 102-75; S. R. Ward, "Intelligence Surveillance of British Ex-Servicemen 1918-20", in: Historical Journal, XVI, pp. 179-88; E. Halévy, The Era of Tyrannies: Essays on Socialism and War (New York, 1966), p. 151.

140 R. Reiss, The House I Want (London, 1919). 
OCCUPATIONS OF LONDON COUNTY COUNCIL RESIDENTS, 1912

Nature of occupation

Number

Agent \& commercial traveller 202

Artist \& draughtsman

Attendant

Baker \& confectioner

Barman

Basket \& brush maker

Boilermaker

Bookbinder

Bootmaker

Boxmaker

Brass finisher

Bricklayer, mason \& plasterer

Butcher

Butler \& servant

Cabdriver \& chauffeur

Cabinet maker

Carman, carrier \& coachman

Carpenter \& joiner

Carpet planner

Cellarman

Charwoman \& cleaner

Checker

Chemist \& analyst

Cigar \& cigarette maker

Clergyman \& churchworker

Clerk

Coachbuilder

Collector

Commissionaire

Compositor

Cook

Costermonger

Cutter

Distemperer \& paperhanger 
Domestic servant $\quad 26$

Dressmaker $\quad 93$

$\begin{array}{ll}\text { Electrician } & 76\end{array}$

Engine \& crane driver $\quad 43$

Engineer $\quad 115$

Engraver $\quad 13$

Farrier $\quad 37$

Fireman $\quad 42$

Fitter \& plumber $\quad 131$

Florist $\quad 14$

Flusher \& sewerman $\quad 10$

Foreman $\quad 75$

Furrier 11

Gardener \& park keeper $\quad 24$

General dealer \& hawker $\quad 48$

Glazier \& glassworker $\quad 22$

Hairdresser $\quad 37$

Hat \& cap maker $\quad 32$

Horsekeeper $\quad 38$

$\begin{array}{ll}\text { Housekeeper } & 48\end{array}$

$\begin{array}{ll}\text { Inspector } & 47\end{array}$

Instrument maker $\quad 52$

Jeweller $\quad 11$

Journalist 16

Labourer $\quad 549$

$\begin{array}{lr}\text { Lamplighter } & 17\end{array}$

Laundry worker $\quad 13$

$\begin{array}{ll}\text { Leather worker } & 46\end{array}$

$\begin{array}{ll}\text { Lighterman } & 42\end{array}$

$\begin{array}{ll}\text { Machinist } & 71\end{array}$

Manager \& manageress $\quad 31$

Mechanic 26

$\begin{array}{ll}\text { Messenger } & 69\end{array}$

Metal worker $\quad 39$

Milkman \& dairyman $\quad 18$

Miscellaneous $\quad 511$

$\begin{array}{ll}\text { Musician \& artiste } & 30\end{array}$

Newsagent $\quad 18$

$\begin{array}{ll}\text { Nurse } & 34\end{array}$

Omnibus \& motor driver $\quad 204$

Omnibus \& motor conductor $\quad 111$ 
Packer

Painter \& decorator

Pensioner

Platelayer

Police constable, sergeant, \& detective

Polisher

Porter

Post office \& telegraphist

Postman

Railway worker, guard \& signalman

Salesman

Sawyer

Seaman \& coastguard

Shipwright

Silversmith \& goldsmith

Soldier

Sorter

Steward

Stevedore

Stoker

Storekeeper

Superintendent \& caretaker

Tailor \& tailoress

Teacher

Theatre worker

Timekeeper

Tinsmith

Turner

Umbrella \& stickmaker

Upholsterer

Waiter \& valet

Waitress

Warehouseman

Watchmaker

Watchman

Waterman \& boatman

Wheelwright

Wireman \& linesman

Woodcarver 